\title{
Impact Analysis of the UC-609 Shipping Package
}

Gregory J. Kay

January 1993

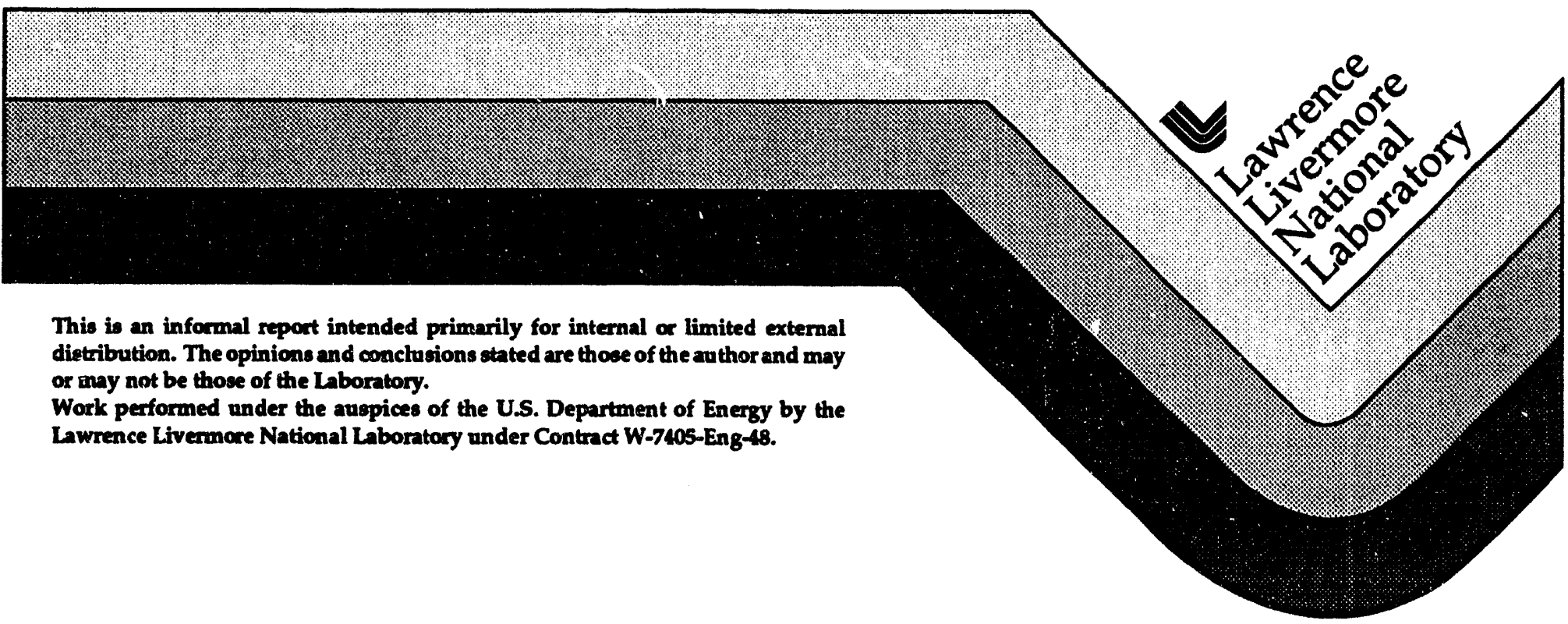




\section{DISCLAIMER}

This document was prepàred as an account of work sponsored by an agency of the United States Government. Neither the United States Government nor the University of Califormia nor any of their employees, makes any warranty, express or implied, or assumes any legal liability or responsibility for the accuracy, completeness, or usefulness of any information, apparatus, product, or process disclosed, or represents that its use would not infringe privately owned rights. Reference herein to any specific commercial products, process, or service by trade name, trademark, manufacturer, or otherwise, does not necessarily constitute or imply its endorsement, recommendation, or favoring by the United States Government or the University of California. The views and opinions of authors expressed herein do not necessarily state or reflect those of the United States Government or the University of California, and shall not be used for advertising or product endorsement purposes.

This report has been reproduced directly from the best available copy.

Available to DOE and DOE contractors from the Onfice of Scientific and Technical Information

P.O. Box 62, Oak Ridge, TN 37831

Prices available from (615) 576-8401, FTS 626-8401

Available to the public from the

National Technical Information Service

US. Department of Commerce

5285 Port Rogal Rd,

Springfield, VA 22161 


\title{
Impact Analysis of the UC-609 Shipping Package
}

\author{
by \\ Gregory J. Kay \\ Applied Mechanics Group
Mechanical Engineering Department
}

January 1993

University of California

Lawrence Livermore National Laboratory

Livermore, California 94550 USA 


\begin{abstract}
The inner containment vessel of the UC-609 shipping container must remain intact and sealed after undergoing a thirty foot drop onto an unyielding surface. The drop scenarios which were considered in this study included top corner down and top down drops. Results of the calculations performed for this study predict structural damage, as measured by accumulated effective plastic strains, but no failure of the inner primary containment vessel for both drop configurations. The top down impact is predicted to produce a higher impact deceleration in the payload but the amount of damage to the primary containment vessel is predicted to be greater for the top corner impact configuration. The critical damage region for both drop scenarios is confined to the containment canister flange region. Verification of the analysis methodology was accomplished by comparing measured top corner crushes with calculated top corner crushes. Acceptable damage levels in this study were determined from calculated damage comparisons between the top corner drop, which remained intact during a top corner impact test, and the calculated top down impact damages. Comparisons were also made on the calculated maximum shear stress levels, which remained near or within NRC regulatory guidelines for both scenarios.
\end{abstract}

\title{
Introduction
}

The Model UC-609 shipping package was developed for the transportation of tritium payloads. A Safety Analysis Report for Packaging (SARP) for the UC-609 shipping package has been written ${ }^{1}$ and documents the package description and structural responses to normal operating conditions. The SARP also documents a top corner drop from a height of thirty feet onto an unyielding surface which resulted in a five inch corner crush of the outer stainless steel drum. The top corner drop was originally assumed to result in the most localized damage to the shipping package but recent concerns have been raised about a direct top down impact of the UC-609 container.

For this study, two thirty foot drop impact configurations were considered. The impact scenarios which were studied included a top corner down impact with the center of gravity over the point of contact and a top d' " $n$ drop. The responses of the UC-609 shipping package to

1 Ron Sandberg, Safety Analysis Report on Model No. UC-609 B(U) DOE Shipping

Package, Lawrence Livermore National Laboratory, UCRL-ID-111494 [1992] 
these impact configurations was simulated with the nonlinear finite element code DYNA3D2 . Verification of the analysis methodology was accomplished by comparing the predicted DYNA3D results with the top corner drop test results for the UC-609 shipping container. The analysis methodology employed in this study is similar to that which was employed in a previous impact analysis on a similar shipping container. The UC-609 shipping package assembly is shown in Figure 1. Details of this assembly can be seen in Reference 1.

\section{Finite Element Analysis Description}

The half symmetry 3-D finite element mesh of the Model UC-609 shipping package is shown below in Figure 2. The mesh components and weights are:

1) Outer SSTL-304 drum - 100 lbs.

2) Celotex/plywood insulation - $110 \mathrm{lbs}$.

3) Inner SSTL-316 containment vessel - 170 lbs.

4) Payload - 120 lbs.

The total simulated weight of the modified Model UC-609 shipping package was $500 \mathrm{lbs}$. The analysis assumed that the shipping container components were in a packed condition, i.e., no initial gaps were assumed between model components. Constants for the material constitutive relationships were obtained from the UC-609 SARP. All materials except the Celotex packing material were modeled as bi-linear elastic plastic materials. The elastic-plastic material constants which were used in the analysis are given below in Table 1. The Celotex was modeled as a crushable foam. This constitutive model, originally developed by $\mathrm{Krieg}^{3}$, allows for the specification of a nonlinear pressure vs. volumetric strain relationship. The deviatoric behavior in the model is elastic-perfectly plastic with a pressure dependent yield function. The shape of the pressure-volumetric strain curve is given below in Figure 3 and the yield-pressure relationship is given in Figure 4. In the Figures 3 and 4 , the deviatoric stress $\mathbf{S}_{\mathbf{i j}}$ is given by $s_{i j}=\sigma_{i j}-\frac{1}{3} \sigma_{k k} \delta_{i j}$, where $\sigma_{i j}$ is the Cauchy stress tensor and the effective stress is defined as $\bar{\sigma}=\sqrt{\frac{3}{2} \mathbf{S}_{\mathrm{ij}} \mathbf{S}_{\mathbf{j i}}}$.

\footnotetext{
2 Whirley, Robert G. , DYNA3D, A Nonlinear, Explicit, Three-Dimensional Finite Element Code For Solid and Structural Mechanics - User Manual, Lawrence Livermore National Laboratury, UCRL-MA-107254 [1991]

${ }^{3}$ Krieg, R.D., A Simple Constitutive Description for Soils and crushable Foams, SC-DR-720833, Sandia Laboratories, Albuquerque, New Mexico, [1972]
} 
Table 1. Elastic-Plastic Material Constants

\begin{tabular}{|c|c|c|}
\hline Location & Outer Drum & $\begin{array}{c}\text { Containment } \\
\text { Vessel }\end{array}$ \\
\hline Material & SS-304 & SS-316 \\
\hline Young's Modulus & $28.4 \times 10^{6} \mathrm{psi}$ & $28.0 \times 10^{6} \mathrm{psi}$ \\
\hline Poisson's Ratio & .27 & .29 \\
\hline Yield Strength & $30,000 \mathrm{psi}$ & $36,000 \mathrm{psi}$ \\
\hline Ultimate Strength & $75,000 \mathrm{psi}$ & $75,000 \mathrm{psi}$ \\
\hline Ultimate Elongation & $50 \%$ & $50 \%$ \\
\hline
\end{tabular}

\section{Finite Element Model Verification - Previous Calculations}

The finite element methodology which was employed in this analysis was verified in a previous shipping container impact study. The shipping container in that study was very similar in geometry and construction to the UC-609 container, with an SSTL-304 outer drum, Celotex packing material and an inner stainless steel primary containment vessel. In the previous study ${ }^{4}$, top corner thirty foot drop tests of the Rocky I; ats Model FL Shipping Container were reported as producing crushes of 4.0 and $4.5^{\prime \prime}$ and a DYNA3D simulation is documented as predicting a crush height of 5.350" (crush distances were measured parallel to the longitudinal axis of the container). Calculated side impact deformations were also compared to FL test results. The calculation predicted crush heights along the longitudinal axis of the FL shipping container which varied from 1.284 " at the bottom of the container to 321 " in the region adjacent to the interior containment canister flange edge. Measured crushes under the same impact conditions varied between $1.25^{\prime \prime}$ and $.25^{\prime \prime}$ along the length of the container.

${ }^{4}$ Kay, G.J. and Hendricks, J.T., Mechanical and Thermal Analysis For Rocky Flats.Model FL Shipping Container, Lawrence Livermore National Laboratory, END92-026 [1992] 


\section{Finite Element Model Verification - Current Study}

A top corner impact simulation of the UC-609 shipping container produced a crush height of 4.724", measured parallel to the longitudinal axis of the container. This can be compared to the measured crush of approximately 5.0" for the UC-609 shipping container under the same impact conditions, i.e., an error of $5.52 \%$. As documented in Reference 1, this impact did not impair the functionality of the UC-609 primary containment vessel. For this report, the responses of the UC-609 primary containment vessel due to a top down drop will be compared to the calculated responses of a top corner drop. The structural integrity of the UC-609 primary containment vessel will be determined by the relative magnitudes of these maximum effective stresses and accumulated effective plastic strains. Adherence to the NRC Regulatory Guide $7.6^{5}$ which set limits on the maximum acceptable stress intensities, i.e., $70 \%$ of twice the maximum shearing stress is also demonstrated in this report.

\section{Results of the Top Corner Down Impact Simulation}

The calculated deformed shape of the UC-609 Shipping Container resulting from a thirty foot top corner drop onto an unyielding surface is shown in Figure 5. A summary of test results is also shown in Table 2. The predicted maximum deceleration of the payload for this configuration is $230 \mathrm{~g}$ 's at $9 \mathrm{msec}$ after impact. Deceleration to zero velocity is expected to occur at 12 msec after impact. Localized effective plastic strains of $14.72 \%$ were calculated in the SSTL-316 containment canister flange region for this load case. Calculated accumulated effective plastic strains in the primary containment vessel flange are shown in Figure 6 . In that Figure, the color fringes represent regions which have undergone permanent deformation. As mentioned above, damage at this level (14.72\% effective plastic strain) did not produce failure in the top corner drop test the UC-609 container. The maximum effective stress which was calculated for the flange region was 47,530 psi and the maximum stress intensity (twice the maximum shear stress) was 56,900 psi. The later level is close to the NRC Regulatory guideline limit of 0.7 times the ultimate stress, i.e., 52,500 psi. Damage to the buckled SSTL304 outer drum is represented by calculated effective plastic strains of $44.27 \%$. In the top corner drop test the drum tie downs were deformed but the drum assembly stayed intact.

5 U. S. Nuclear Reguiatory Commission Regulatory Guide, Design Criteria For The Structural Analysis of Shipping Cask Containment Vessels, May 1977 


\section{Results of the Top Down Impact Simulation}

The predicted deformed shape resulting from a top down thirty foot drop of the UC-609 shipping canister onto an unyielding surface is shown in Figure 5. The predicted amount of Celotex crush, measured parallel to the longitudinal axis, is $0.536 "$. The predicted maximum deceleration of the payload for this impact configuration is $412 \mathrm{~g} / \mathrm{s}$ at $5 \mathrm{msec}$ after impact. Deceleration to zero velocity for this configuration is expected to occur at $7 \mathrm{msec}$ after impact. The SSTL-316 primary containment vessel flange region is expected to see permanent damage as a result of a top down impact where localized effective plastic strains of $8.02 \%$ are expected in the flange region of the inner containment vessel. Predicted fringes of accumulated effective plastic strains in the flange region are shown in Figure 6. The highest intensity effective plastic strain regions, represented by the red and red-yellow fringe regions can also be compared for the top down and top corner drop impacts in Figure 6. As can be seen, the top down impact produces less accumulated damage to the flange region than the top corner impact. The maximum effective stress which was calculated for the flange region was 42,230 psi and the maximum stress intensity was $48,560 \mathrm{psi}$. The later level being within the NRC Regulatory guireline of $52,500 \mathrm{psi}$. This maximum stress intensity can also be compared to the $56,900 \mathrm{psi}^{\dagger}$. sity calculated for the top corner impact configuration. Effective plastic strains of $14.07 \%$ are predicted to occur in the outer SSTL-304 drum but the outer drum assembly is expected to retain intact as these strains can be compared to the $44.27 \%$ outer drum effective plastic strains which were calculated for the top corner drop.

\section{Summary of UC-609 Impact Simulations}

Top corner and top down drops from heights of 30 feet should produce structural damage but no rupture of the outer drum of the UC-609 Shipping Container. The top down impact is calculated to produce a higher impact deceleration in the payload but the amount of damage to the primary containment vessel is predicted to be greater for the top corner impact scenario. Based on a comparison of damage between the top corner and top down accident scenarios, the top down impact is expected to remain functional. 
Table 2. Top Down Drop Simulation Results For the Model UC-609 Shipping Container

\begin{tabular}{|c|c|c|}
\hline Load Case & Top Corner Drop & Top Down Drop \\
\hline $\begin{array}{c}\text { Celotex Packing } \\
\text { Material Crush }\end{array}$ & 4.724 inches & 0.536 inches \\
\hline $\begin{array}{c}\text { Max. } \overline{\mathbf{\varepsilon}}^{\mathrm{p}} \text { in Outer } \\
\text { Drum } \mathbf{1}\end{array}$ & $44.27 \%$ & $14.07 \%$ \\
\hline $\begin{array}{c}\text { Max. } \overline{\boldsymbol{\varepsilon}}^{\mathrm{p}} \text { in } \\
\text { Containment } \\
\text { Vessel Flange } \\
\text { Region }\end{array}$ & $14.72 \%$ & $8.02 \%$ \\
\hline $\begin{array}{c}\text { Twice Max. } \\
\text { Shear Stress in } \\
\text { Containment } \\
\text { Vessel Flange } \\
\text { Region }\end{array}$ & $56,900 \mathrm{psi}$ & $48,560 \mathrm{psi}$ \\
\hline $\begin{array}{c}\text { Max. Effective } \\
\text { Stress in } \\
\text { Containment } \\
\text { Vessel }\end{array}$ & $47,530 \mathrm{psi}$ & $42,230 \mathrm{psi}$ \\
\hline $\begin{array}{c}\text { Max. } \\
\text { Acceleration of } \\
\text { Payload }\end{array}$ & $230 \mathrm{~g}$ 's & $412 \mathrm{g's}$ \\
\hline $\begin{array}{c}\text { Deceleration } \\
\text { Time for Payload }\end{array}$ & $.012 \mathrm{msec}$ & $.007 \mathrm{msec}$ \\
\hline
\end{tabular}

1) $\overline{\boldsymbol{\varepsilon}}^{\mathrm{p}}=$ effective plastic strain 


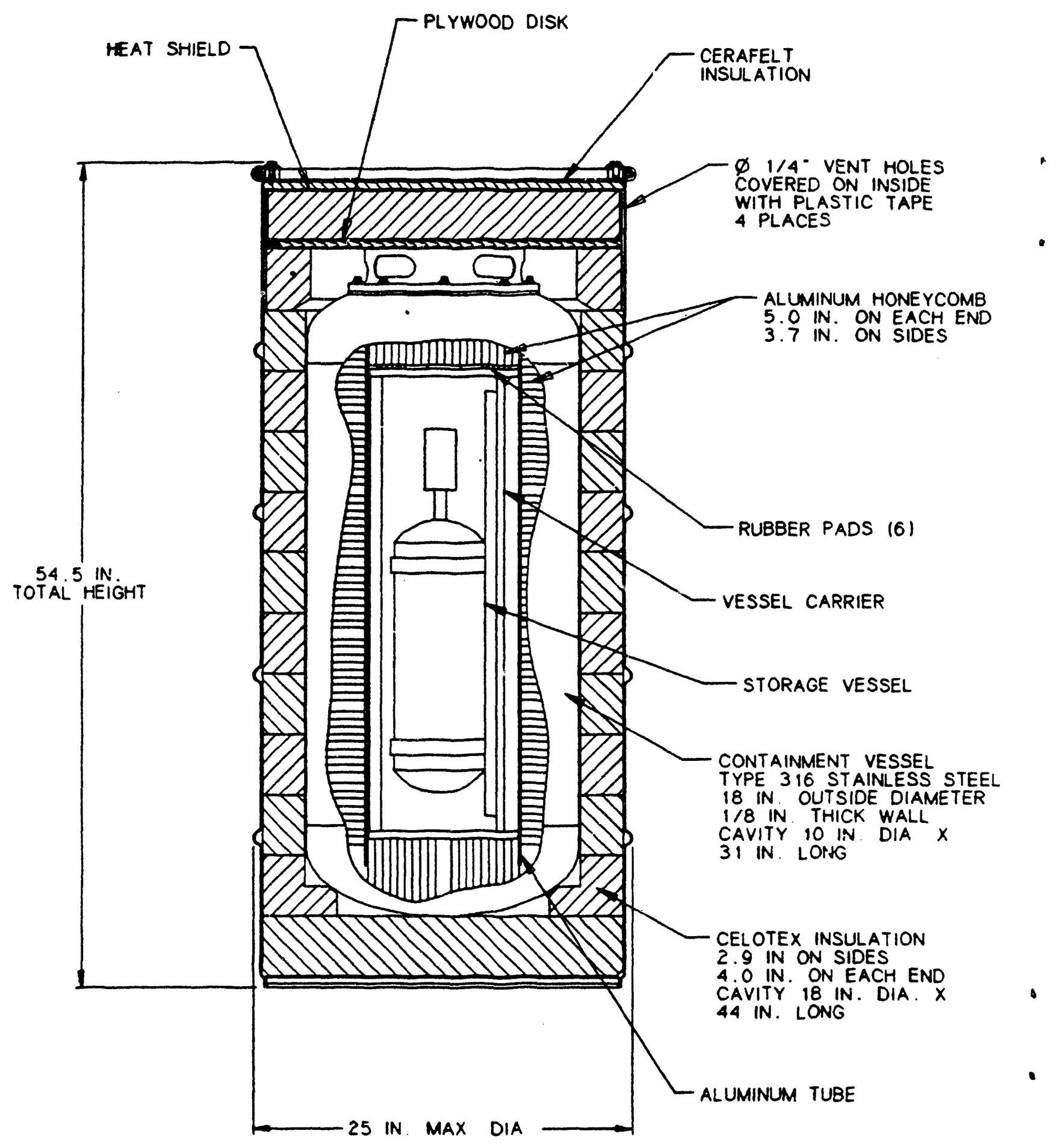

Figure 1. Shipping Container Overall Assembly , 


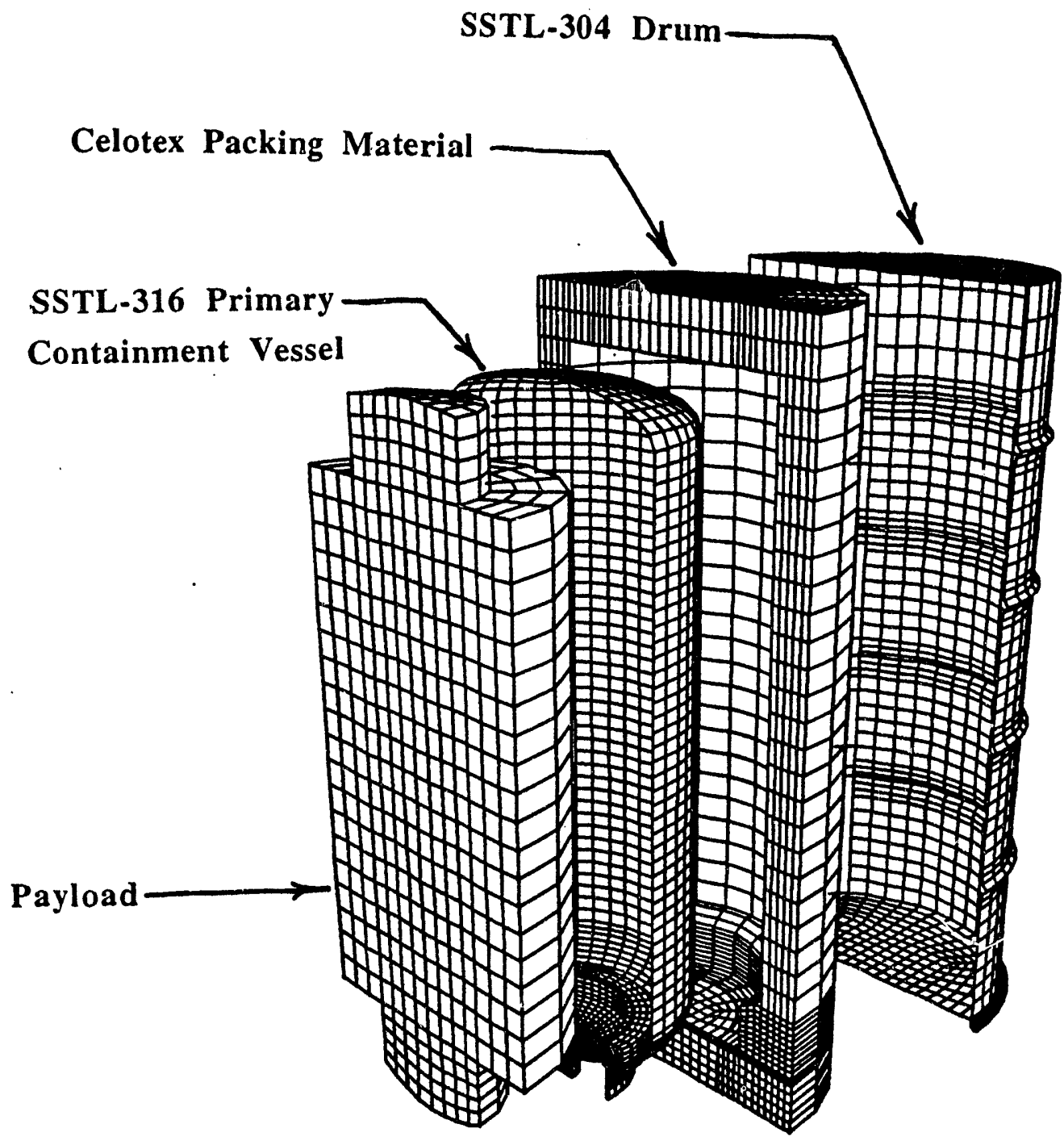

Figure 2. UC-609 Shipping Canister Finite Element Model 


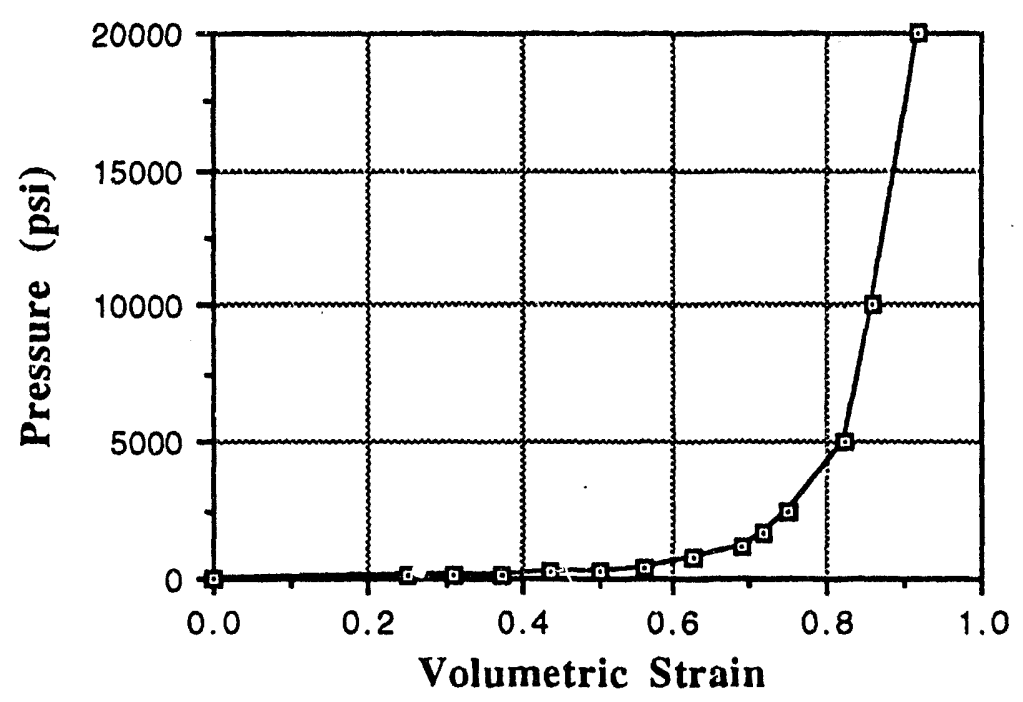

Figure 3. Assumed Volumetric Strain vs. Pressure Relationship for Celotex

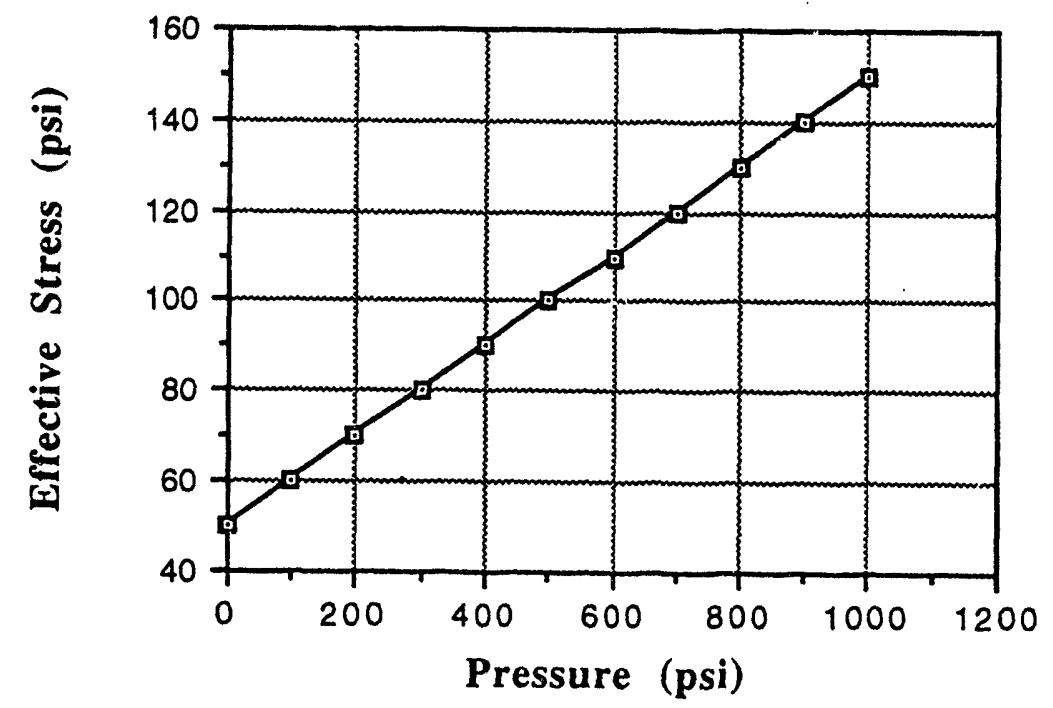

Figure 4. Assumed Effective Stress versus Pressure Relationship For Celotex 

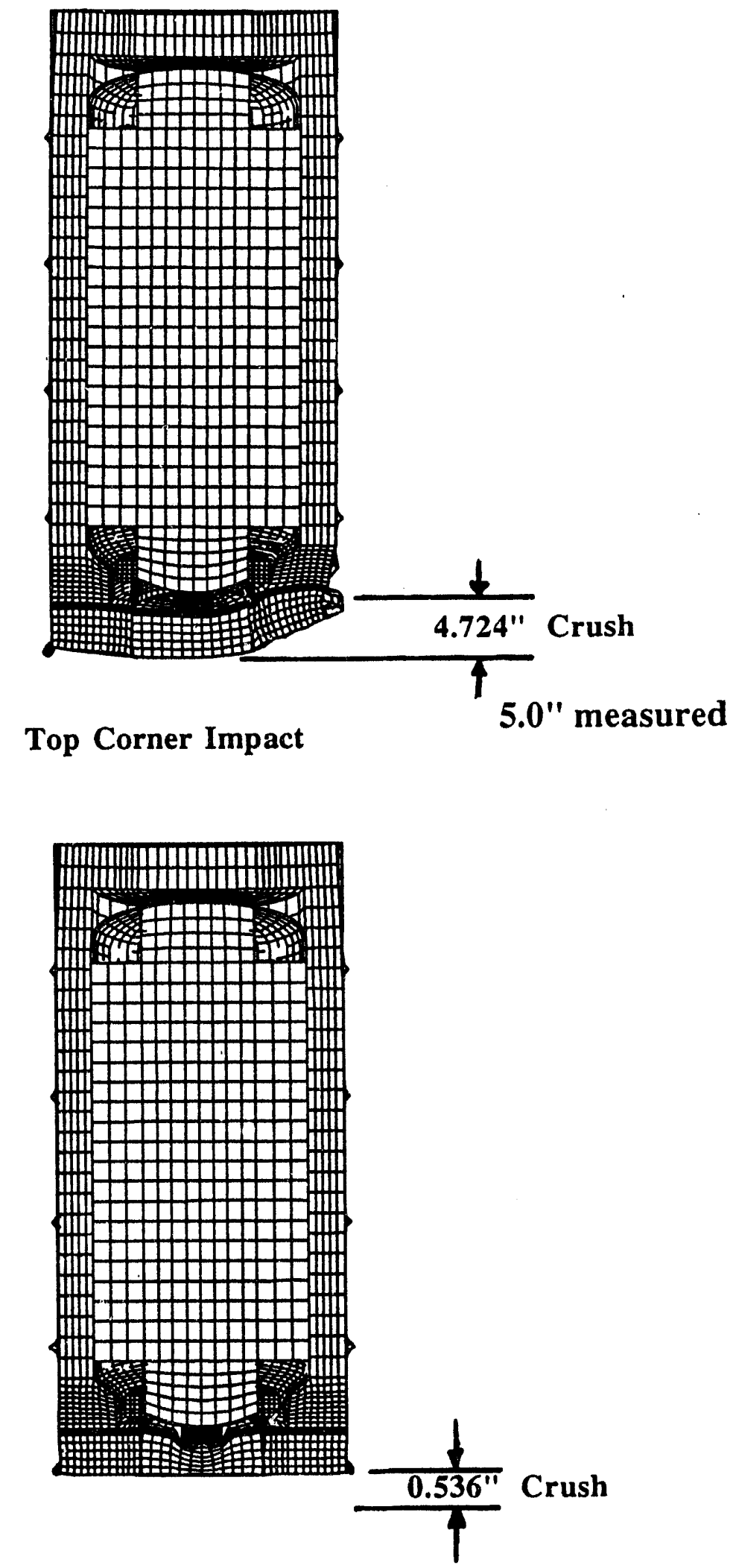

Top Down Impact

Figure 5. UC-609 Deformed Shapes Resulting From a 30 Foot Drop Onto An Unyielding Surface 

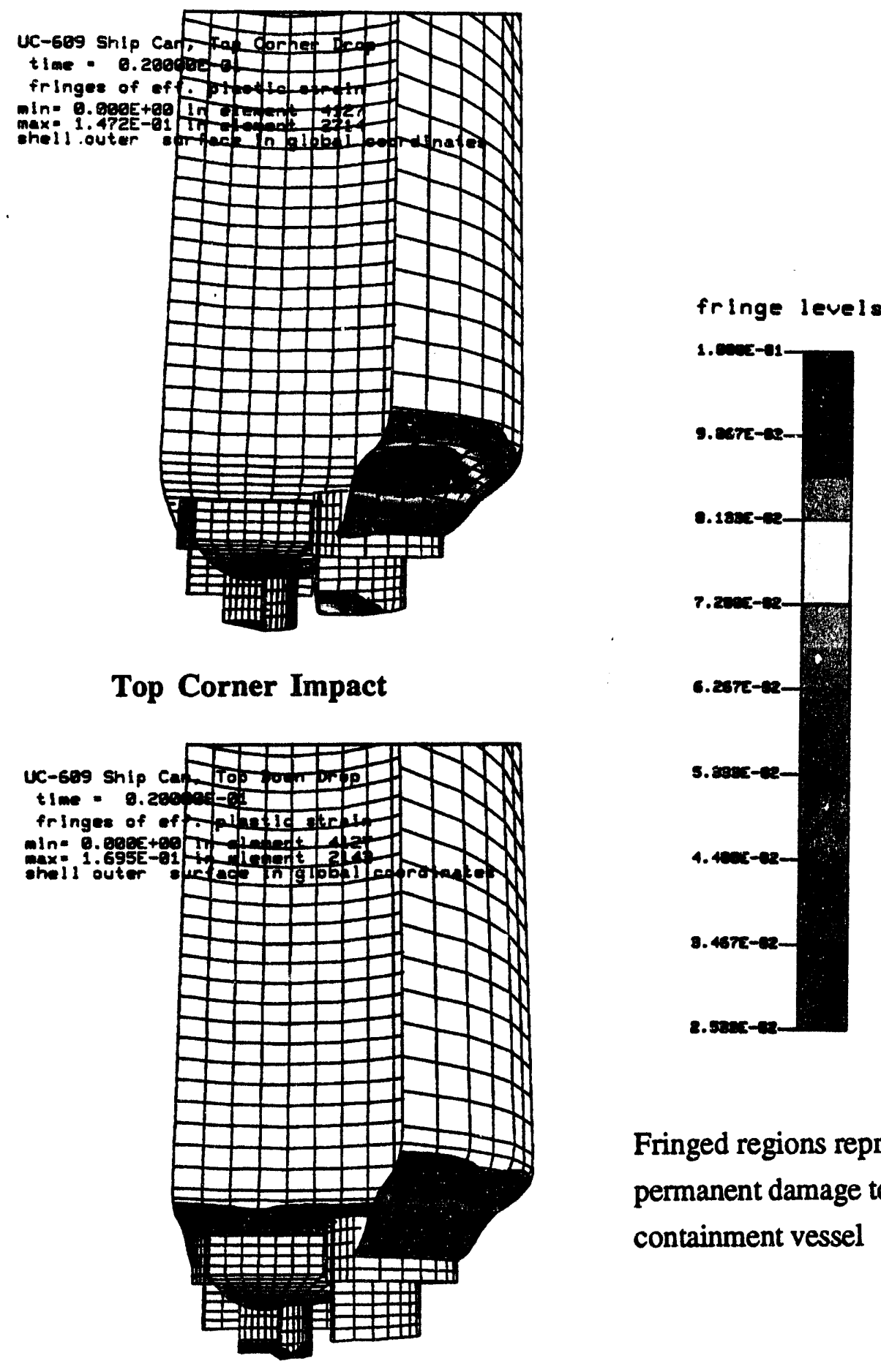

Top Corner Impact

Top Down Impact

Fringed regions represent permanent damage to containment vessel

Figure 6. UC-609 Effective Plastic Strain Regions Resulting From a 30 Foot Drop Onto An Unyielding Surface 

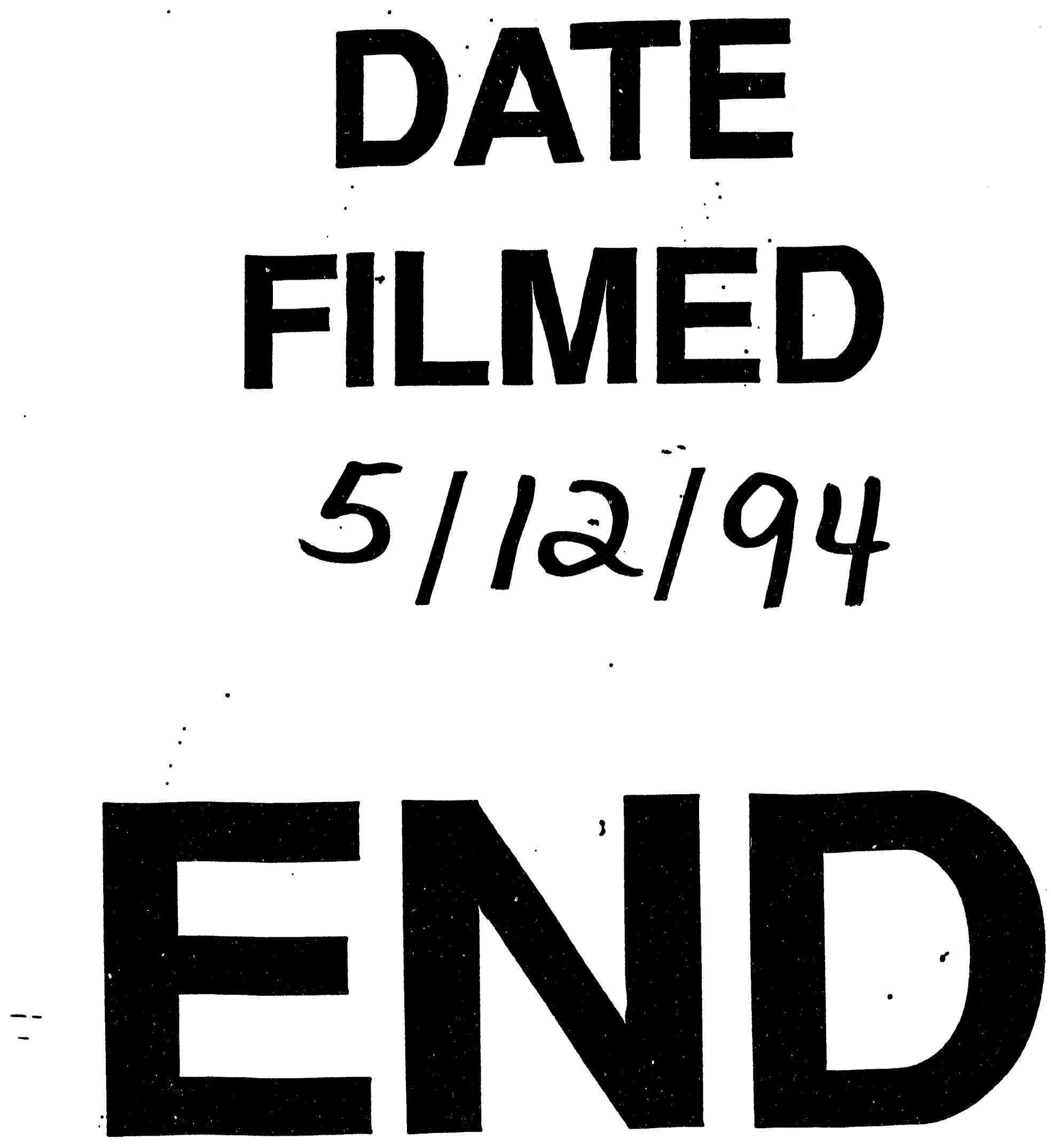
